

Arne Johan Vetlesen Professor i filosofi, Universitetetioslo

\section{Empati \\ under press}

\author{
New Public Management-reformer i psykisk helsevern gjør at helse- \\ personell kommer i skvis mellom krav om økt effektivitet og faglig \\ og moralsk integritet.
}

www.sykepleien.no

Les mer og finn litteraturhenvisninger på våre nettsider.

\section{Søkeord:}

>morganisering

I Etikk

> Psykeisk helsearbeid

> Arbeidsmiljø

- Arbeidstaker denne artikkelen vil jeg diskutere hva slags omkostninger de siste års reformer innen psykisk helsevern har fătt for de berørte, især sykepleiere. Erfaringene er langt på vei felles for ulike profesjoner innen offentlig sektor som siden 1990-tallet har vært gjenstand for reformer inspirert av New Public Management (defineres nærmere nedenfor). Den man - som sykepleier, terapeut, pedagog - til enhver tid arbeider med, er enkeltmennesket. Oppgaven består i å møte denne personens behov på en måte som kan anses faglig forsvarlig og etisk riktig av fagpersonen så vel som av mottakeren. Når reformer innført fra det administrative ledelsesnivået truer kvaliteten ved giver-mottaker-relasjonen, (pleierpasient) har vi å gjøre med det jeg i denne artikkelen vil omtale som omkostninger.

\section{Stadig nye reformer}

I boken «Umyndiggørelse» undersøker den danske sosiologen Rasmus Willig vilkårene for å bedrive faglig fundert kritikk blant en gruppe pedagoger i Århus (1). Pedagogene har i 15 år vært gjenstand for reformer initiert av politiske myndigheter. Strukturer og rammevilkår endres kontinuerlig, og alt pedagogene gjør i løpet av en arbeidsdag måles for å kartlegge om «effektiviteten øker» og om «tidsbruken er optimal». For dem som jobber på gulvet medfører reformene en rekke dilemmaer: Spar på budsjettet/styrk arbeidsmiljøet; Konsentrer deg om det enkelte barns utviklingsbehov/følg opp flere barn for færre ressurser. Intensiveringen av slike dobbeltbindende arbeidsoppgaver fører til handlingslammelse. For mange blir det umulig å erkjenne hvilke angitte arbeidsoppgaver som er viktigst, når alle er formulert som positive. Den enkelte pedagog klarer ikke å realisere den ene pålagte målsettingen uten å undergrave andre.

\section{Varsling blir kverulering}

Følgende mønster avtegner seg: Den enkelte pedagog påpeker oppgavenes uforenlighet, men blir møtt med en rekke avvæpningsstrategier fra den kommunale ledelse. Smakebiter: «Man kan alltid bli litt bedre, ikke sant?» «Tiden for kritikk av det nye er forbi; det toget har gått og det gjelder å være konstruktiv, altså å se fremover.» «Konkurranse er alltid av det gode, bare det forstås som at man må konkurrere med seg selv.» Og som et siste trumfkort fra ledelsen overfor en medarbeider som insisterer på at ubehaget ved reformene er saklig begrunnet: «Dersom du ikke liker lukten i bakeriet, kan du jo bare forlate det.» Kritikk ytret oppover i systemet, ofte basert på årtiers erfaring og faglig etablerte standarder for hva som er forsvarlig profesjonsutøvelse, demonteres og returneres til avsender i individualisert utgave: «Her er en medarbeider som ikke forstår de nye krav, skaper et negativt miljø og utgjør et samarbeidsproblem som best kan løses ved at vedkommende forsvinner - eller tier still.» Systemkritikk avpolitiseres og ufarliggjøres, den vendes om 180 grader, forvandles til en kritikk av avsenderen som individ. Du har valget mellom å bli syk fordi du sa fra, eller bli syk fordi du lar være, selv om du synes du burde. Varsling blir til kverulering, protest blir til personalsak.

\section{Redusere kostnader}

Etter denne visitten innom Willigs funn, skal vi vende blikket mot norske forhold. Sosiologen Mia Vabø (2) forteller i artikkelen «Kvalitetsretorikk i norske kommuner» at hun på slutten av 1990-tallet deltok på et seminar om «total kvalitetsledelse» (TQM: «Total Quality Management»), arrangert for administrative sjefer innen den kommunale eldreomsorgen i Norge. Hun husker hvordan seminarlederen med enkle beskrivelser demonstrerte hvordan det var mulig, gjennom en systematisk og analytisk arbeidsmåte, å redusere kostnader og å øke kvaliteten på en og samme gang. For tilhørerne, som strevde med knappe budsjetter, fremsto budskapet om å slå to fluer i en smekk som forlokkende (2). Vabø er slått av hvordan ledelsesretorikken er gjennomsyret av en språkbruk der kvalitetssystemer og -beslutninger omtales som verktøy, og organisasjoner som forvokste individer (organismer) med en egen identitet. Ledelsen er hodet og medarbeiderne nedover i systemet er kroppen, og samspillet mellom de to må være så intimt og dynamisk som mulig for å sikre optimal måloppnåelse, utlagt som 
«best kvalitet for brukerne». Kvalitetssystemene generelt og de nye kontroll- og evalueringsrutinene spesielt, beskrives ved hjelp av metaforer der samtlige medarbeidere mobiliseres i en felles kraftanstrengelse for organisasjonen. Kvalitetssystemene skal for all del ikke fremstå som noe fremmed eller utvendig, noe unaturlig eller påtvunget. I stedet presenteres de som et organisk uttrykk for identiteten og motivasjonen til hver medarbeider. Alt handler om samhandling. De nyinnførte kvalitetssystemene beskrives som «medarbeidernes eiendom», noe hver og en må utvikle en følelse av eierskap til, investere av seg selv i. «Et levende system» som «sitter i ryggmargen på medarbeiderne»; et system som «får alle til å dra i samme retning». Alle har som felles mål å sørge for at det samlede resultatet blir tilfredsstillende for alle berørte. Som en ledelseskonsulent sammenfatter: «Kvalitetsledelse er sunn fornuft satt i system» (2, s. 156).

\section{Kopierer privat sektor}

Formuleringen illustrerer hvordan New Public Management-inspirerte reformer fremstår som ikke-ideologiske og politisk nøytrale, ja som hevet over «gamle» skille- og konfliktlinjer. Reformene fremstår som objektive. Hvem som står bak dem holdes skjult. Politiske myndigheter og økonomisk-administrativ ledelse skyver pasientene, unnskyld «brukerne» - og i stigende grad: «kundene» - foran seg, og foregir å fremme det beste for dem på en måte som intet fornuftig menneske kan være kritisk til. Premisset i NPM er at virksomheter innen offentlig sektor (helse, skole, utdanning, transport, energiforsyning, medier) har alt å vinne på å kopiere

\section{Varsling blir til kverulering, protest blir til personalsak.}

privat sektor, særlig når det gjelder tidsbruk og ressursutnyttelse, forstått som kostnadseffektivitet. Ingen fellesskapsoppgave - for å snakke gammeldags - skal være skjermet mot bunnlinjens forrang. Det vil si at kravet om å drive konkurransedyktig, i et marked med dels statlige og kommunale, dels rent privatkapitalistiske konkurrenter, har høyeste prioritet. Konkurransesituasjonen som 
et marked skaper, er i seg selv å anse som stimulerende (et «insitament») for bedre kvalitet hos den enkelte tjenesteyter («aktør» i NPM-sjargong).

Tankegangen innebærer at det alltid er offentlig sektor som har noe å lære av privat - aldri omvendt. Kontrasten offentlig/privat får dermed en klar normativ betydning, den ikke-ideologiske fasaden til tross. «Offentlig» tolkes som avleggs, fortidspreget, statisk, rigid, treg, kolossaktig, paternalistisk, kollektivistisk, tvangsmessig. «Privat» konnoterer det rakt motsatte: fremtidsrettet, dynamisk, fleksibelt, individuelt, frigjørende. Argumentet slår knockout på alle andre argumenter: det ene har «gått ut på dato», det andre har verden for sine føtter. Den som vil minne om at offentlige oppgaver og virksomheter har en annen egenart enn private, som er svært forskjellig fra kommersielt kjøp og salg av varer på et marked, sitter med dårlige kort. Forbilde- og modellfunksjonen til det private overfor det offentlige er hevet over enhver diskusjon.

\section{Motstand bekjempes}

Vabø kommenterer et hefte utgitt av Helsetilsynet i 1998, kalt «Kvalitetsstyrte helseorganisasjoner - til deg som leder». Her gis anbefalinger om hvordan sjefer og ledelseskonsulenter skal gå frem for å bekjempe alle former for forandringsmotstand. I dette perspektivet betraktes motstand mot nye kvalitets- og kontrollsystemer som «arbeidstakernes (for eksempel sykepleieres) motstand mot å miste egne privilegier». Det vil si at «motstanden relateres til medarbeidernes egeninteresser og settes i kontrast til hjelpemottakernes interesser. Å gjøre motstand mot kvalitetsavgjørelser blir med andre ord ensbetydende med å gjøre motstand

\section{Man splitter personell og mottakere, og setter sistnevntes påståtte interesser opp mot førstneunte.}

mot forbedringer for hjelpemottakerne. Her ligger en implisitt antakelse om at forandringsmotstand ikke er forenlig med hjelpemottakernes interesser» (2, s. 157).

Når den administrative ledelsen tolker fagpersonellets motstand mot omlegginger som et uttrykk for personalets egeninteresser (eller profesjonsinteresser), og videre går ut ifra at slike interesser er i konflikt med hva som er til mottakernes (pasientenes) beste, er dette etter mitt syn ren hersketeknikk. Man splitter personell og mottakere, og setter sistnevntes påståtte interesser opp mot førstnevnte. Budskapet er at den som motsetter seg nye rutiner, begår et svik mot de hjelpetrengende mottakerne, altså mot den svake part. Dette er det moralske stinget i ledelsens tolkning av forandringsmotstand hos dem som jobber på gulvet.

\section{Empati og skjønn}

Mange av de ansatte Vabø har snakket med innenfor den kommunale eldreomsorgen, peker på at beslutninger og planer som legges på et overordnet nivå gir visse retningslinjer for arbeidet. Men de presiserer at disse retningslinjene aldri kan styre arbeidet fullt og helt. Omsorgsarbeid krever hele tiden menneskelige valg og beslutninger. Som Aristoteles (3) understreker: Hva som er rett å gjøre akkurat nå, overfor akkurat denne pasienten, gitt hennes sykdomshistorie, personlighet og tilstand, lar seg ikke forhåndsbestemme i forordninger av et generelt slag. Her-og-nå-situasjonen er ikke en enkel repetisjon av forutgående tilfeller; noen ganger må én faktor, andre ganger en annen eller en tredje, gis størst vekt. Det omsorgsarbeideren gjør sin innstas overfor, er et levende og unikt menneske hvis situasjon (behov, forventninger, engstelser og håp) er i forandring. Et subjekt i bevegelse, hvis eksakte bevegelse må fanges opp og tas hensyn til av omsorgsarbeideren. Her kreves en dynamisk blanding av erfaring og skjønn, en mulighet til å søke rettledning i tidligere erfaringer, i frem-og-tilbakebevegelse med skjønn, forstått som evnen til å se det nye, det ikke-før-erfarte i denne pasientens situasjon.

Spillerommet for utøvelse av skjønn i denne forstand, snevres inn i kjølvannet av de reformene vi her taler om. Skjønn kommer under samme press som empati gjør, og av samme årsaker. La meg forklare.

Slik jeg bruker ordet, handler empati om min evne til å bli følelsesmessig berørt av andres berørthet. Slik berørthet er noe annet enn en ren kognitiv registrering av at du har det slik eller slik. Berørtheten ved å stå overfor din berørthet, innebærer en deltakelse i din opplevelse, til forskjell fra at jeg betrakter den fra utsiden. Deltakelsen betyr ikke at jeg blir smittet, eller direkte kopierer din opplevelse, den tristhet, redsel eller angst som du viser. Jeg berøres av å se hvor engstelig du nå fremstår, uten at jeg dermed selv blir engstelig. Empatiens kjerne er ikke å føle eller oppleve det samme som den andre. Det er å bli engasjert i hva den andre opplever, selve det at den andre har det slik eller slik. Min respons vil grovt sagt samsvare med graden av alvorlighet jeg oppfatter hos den andre. Og der slik korrelasjon er fraværende, vil vi finne fraværet påfallende og søke en forklaring. Kort sagt: Min berørthet vekkes, avstemmes og kanaliseres av din $(4,5)$.

\section{Krever tid}

Empati og skjønn har en felles forutsetning: tid. Tid er en forutsetning for tillit. For at en pasient kan føle seg trygg på en pleiers ønske om og kompetanse i å gjøre godt mot pasienten, lindre, trøste, møte - akkurat her og nå, overfor akkurat denne pasienten, kreves tid. Å motta rapport ved vaktskifte, å bla i journalen og lese siste epikrise, er én ting. Å bli kjent med pasienten som unik person, er noe annet. Det krever sin tid. Ro til å sette seg ned, til å prate, lytte og fortelle. Samt å legge merke til alt pasienten kommuniserer nonverbalt, ved gestene, ved blikket, ved hånden, ja, ved hele holdningen som kropp og sjel, hender og øyne, utstråler mot pleieren. Som pleier må jeg ha mulighet - tid og rom - for å dvele ved denne pasientens situasjon, for å danne meg et grunnlag for å vite hvordan jeg skal handle.

Skjønn adresserer, og nødvendiggjøres av, partikularitet, av enkelttilfellets egenart. Skjønn retter seg dermed mot det som ikke lar seg strømlinjeforme, forutse og beregne i samsvar med kvantitative prosedyrer, målestokker og tenkemåter. Tenkemåter som har sitt opphav i bedriftsøkonomiske modeller, og som ikke lar seg overføre til et menneskelig, kvalitativt felt som omsorg uten å skade dets egenart.

Disse tause, rent kvalitative dimensjonene ved hva pleie er og hva god pleie krever, i tid og rom, av empati og utøvelse av skjønn, har kommet under særlig press gjennom de siste års New Public Management-reformer. Det er som om reformene, med sine kvantitative målestokker og homogeniserende prosedyrer, stammer fra et annet univers. Dette universet er uforenlig med pasientens opplevde livsverden, og det som preger pleier-pasientkommunikasjonen av tilstand og behov, smerte og lindring.

\section{Moralsk problem}

At spillerommet for utøvelse av erfaringsbasert skjønn skrumper 
inn, gir seg ulike utslag. Vabøs materiale viser at omsorgspersonalet opplever «en økende kløft mellom hva de burde gjøre for de pleietrengende, og hva de faktisk kan gjøre». Hun forklarer: «Til forskjell fra ledelsen som ser gapet mellom sosialpolitiske mål og ressurser som et organisatorisk problem, opplever medarbeiderne det som et moralsk problem. Dilemmaet setter seg i kroppen som 〈dårlig samvittighet〉 og 〈utilstrekkelighet»» (2, s. 159). Dette stemmer med hva Willigs pedagoginformanter rapporterer. Belastningene ved å sette de nye arbeidsrutinene og evalueringsmålene som dikteres ovenifra ut i livet, setter seg i kropp og sinn hos den enkelte medarbeider (pleier). Med andre ord: Selv om belastningene ved «effektivisert» ressurs- og tidsbruk er systemisk betinget, forårsaket av et bestemt økonomisk-administrativt ledelsesregime, arter belastningene seg som konkrete individuelle belastninger hos pleier A og pleier B. Hodepine hos A, stivhet i nakkemusklene hos B, og atter annerledes hos andre. Slik individualisering av reformenes negative konsekvenser er karakteristisk for hvordan motstand avpolitiseres og avideologiseres, ja fratas sitt faglige fundament. Motstand nedenfra blir ikke møtt ovenfra som det systeminduserte problemet det er, men (omfor-) tolkes i stedet til et problem hos pleier A eller pleier B, som må takles deretter individuelt, ikke systematisk.

\section{Individuelt ansvar}

Fenomenet det handler om kan beskrives slik: Nyliberalismen generelt og New Public Management-inspirerte reformer spesielt, fremholder individuelt ansvar på alle nivåer i organisasjonen som en av reformenes viktigste goder. Både «individuelt» og «ansvar» er unektelig honnørord. De har her en tilslørende funksjon. Poenget er at den individualiseringen som foregår etterlater ansvaret, som pålegges den enkelte medarbeider på organisasjonens nedre nivåer, i et maktmessig vakuum. Den enkelte medarbeider på gulvet pålegges ansvar for antallet stelte pasienter på avdelingen i løpet av kvelden, antallet gjennomførte hjemmebesøk, antallet vaskede toaletter og så videre. Men det følger ingen beslutningsmakt eller ressurser med dette personbundne ansvaret for utført jobb (oppnådd produksjonsmål), som står i forhold til ansvaret. Medarbeideren gis med andre ord mer å svare for, men mindre å svare med.

Den politiske filosofen Brian Barry skriver: «Når det foreligger et dårlig resultat (manglende måloppnåelse), kan to ulike tilnærminger benyttes: en som appellerer til den enkelte medarbeider om å tilpasse seg i betydningen yte mer; og en som krever endringer i medarbeiderens omgivelser og rammebetingelser» (6, s. 150). Når alt fra kommunale omsorgstjenester til multinasjonale konserner bruker store ressurser på å fremme en «cult of personal responsibility» (6), gjør de samtidig hva de kan for å gi forrang til den første tilnærmingen, til forkleinelse for den andre. Å gi forrang til den andre ville medføre krav om endringer av en overordnet, systemisk art. Det ville innebære at den enkelte ble oppfordret til å sette spørsmålstegn ved legitimiteten til de store strukturene. Mikronivået ville ansvarliggjøre makronivået, gulvet stille toppen til ansvar for et dårlig resultat. De som nå opplever en individuell ansvarliggjøring, vil returnere den til avsender med spørsmål om de på lavere nivå har de ressurser og den innflytelse som trengs dersom ansvarliggjøringen skal samsvare med maktforholdene i egen arbeidshverdag.

Det er dette siste som nettopp ikke skjer. Ansvarstilskriving for et dårlig resultat er gitt en ovenfra-ned, ikke nedenfra-opp karakter. Den økonomisk-administrative makten som iverksetter NPM-reformer, retter lyskasteren mot den enkelte påtrufne medarbeider på lavere nivå («hva har sviktet her, og hvem?»). Ved å zoome inn på enkeltindividets ytelse mørklegges de overordnede strukturene og rammebetingelsene. De går fri fra kritisk oppmerksomhet med henblikk på hva som der, på selve systemnivået, forårsaker det som fremstår som «individuell svikt».

\section{Individuelt valg}

I våre dager finner også et annet skifte sted når det gjelder spørsmålet om hvem som gis ansvar for et uønsket resultat. Jeg tenker på skiftet fra tilbyder til kunde, eller om man vil, fra tjenesteyter (organisasjon, selskap) til bruker. Logikken er følgende: Oppgaver av typen helse, omsorg og utdanning «liberaliseres» og får markedskarakter, slik at mange tjenesteytere (noen statlig/kommunale, andre private) konkurrerer om kundenes (brukernes) gunst. Dette medfører at den enkelte bruker må gjøre sine strikt individuelle valg av tjenesteyter: A snarere enn konkurrentene B, C og D. Når man så blir skuffet over resultatet (hva som faktisk leveres), så blir man skuffet i rollen som en konsument som har gjort et ikke-optimalt valg på et fritt marked. Kort sagt: man blir minnet om at man jo kunne ha valgt annerledes.

Det er altså to måter for en organisasjon å unndra seg systemisk ansvar på, eller om man vil: ansvar som organisasjon og i en forstand som ledelsen må svare for. Den ene måten er vertikal og intern: Å skyve ansvaret nedover langs tjenestevei, slik at dårlig resultat knyttes til en - eller noen få - medarbeidere. Siden problemet viser seg å ha en slik individuell karakter, må det også løses individuelt - det er logikken. Den andre måten er horisontal og ekstern: Å overgi ansvaret til den enkelte bruker, betraktet av organisasjonen, og i økende grad av seg selv, som en autonom konsument (kunde, bruker) av tjenestene det er tale om. Her blir den til nylig oppleste og vedtatte heteronome person, nemlig den syke og hjelpetrengende, satt i samme kategori som alle andre angivelig autonome velgere av tjenester, eller av behandlingsopplegg.

\section{Dårlig samvittighet}

Det oppstår et dilemma mellom krav som stilles ovenifra om økt effektivitet, og det som både faglig og moralsk integritet tilsier. Hos mange som jobber i omsorgsyrkene skaper dette en opplevelse som det ikke står noe om i materiellet utsendt fra ledelseshold; opplevelsen av å sitte med dårlig samvittighet for å ha bidratt til for stor produktivitet. Man hadde følt seg bedre, som fagperson og som medmenneske, dersom man hadde pleiet færre pasienter, altså dersom man hadde hatt mer tid med hver enkelt. I stedet legger systemet opp til at man skal rekke over flest mulig på kortest mulig tid. En vanskelig situasjon for dem som har arbeidsdagen sin i direkte kontakt med pasientene og deres behov, som verken følger klokke eller budsjett. Den enkelte helsearbeider er således satt i en «no win situation», der alternativene består i å ta belastningen det innebærer å sette alt inn på å nå de dikterte målene, eller belastningen det innebærer ikke å nå dem. IIII

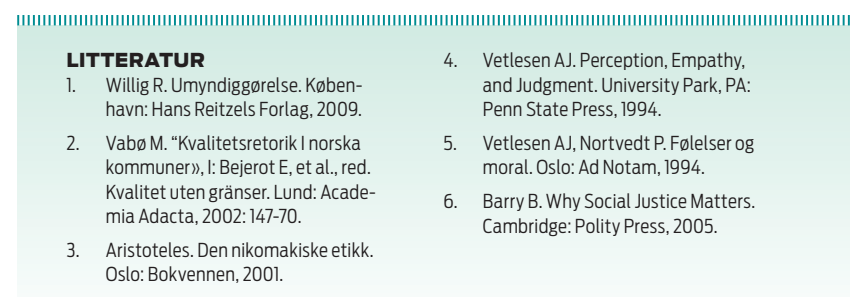

